\title{
The role of periostin in tissue remodeling across health and disease
}

\author{
Simon J. Conway • Kenji Izuhara • Yasusei Kudo • \\ Judith Litvin • Roger Markwald · Gaoliang Ouyang • \\ Joseph R. Arron · Cecile T. J. Holweg • Akira Kudo
}

Received: 20 August 2013 / Revised: 4 October 2013 / Accepted: 7 October 2013 / Published online: 22 October 2013

(C) The Author(s) 2013. This article is published with open access at Springerlink.com

\begin{abstract}
Periostin, also termed osteoblast-specific factor 2, is a matricellular protein with known functions in osteology, tissue repair, oncology, cardiovascular and respiratory systems, and in various inflammatory settings. However, most of the research to date has been conducted in divergent and circumscribed areas meaning that the overall understanding of this intriguing molecule remains fragmented. Here, we integrate the available evidence on periostin expression, its normal role in development, and whether it plays a similar function during pathologic repair, regeneration, and disease in order to bring together the different research fields in which periostin investigations are ongoing. In spite of the seemingly disparate roles of periostin in health and disease, tissue remodeling as a response to insult/injury is emerging as a common functional denominator of this matricellular molecule. Periostin is transiently upregulated during cell fate changes, either physiologic or pathologic. Combining observations from
\end{abstract}

All authors contributed equally.

\section{S. J. Conway}

Program in Developmental Biology and Neonatal Medicine, Wells Center for Pediatric Research, Indiana University School of Medicine, Indianapolis, IN, USA

\section{K. Izuhara}

Division of Medical Biochemistry, Department of Biomolecular Sciences, Saga Medical School, Saga, Japan

\section{Y. Kudo}

Department of Oral Molecular Pathology, Institute of Health Biosciences, The University of Tokushima Graduate School, Tokushima, Japan

J. Litvin

Department of Anatomy and Cell Biology, Temple University

School of Medicine, Philadelphia, PA, USA various conditions, a common pattern of events can be suggested, including periostin localization during development, insult and injury, epithelial-mesenchymal transition, extracellular matrix restructuring, and remodeling. We propose mesenchymal remodeling as an overarching role for the matricellular protein periostin, across physiology and disease. Periostin may be seen as an important structural mediator, balancing appropriate versus inappropriate tissue adaption in response to insult/injury.

Keywords Periostin · Extracellular matrix $\cdot$ Remodeling · Repair

\section{Introduction}

Periostin, also termed osteoblast-specific factor 2, is a 93.3 kDa-secreted, vitamin K-dependent glutamate-containing matricellular protein, originally isolated from a

\author{
R. Markwald \\ Department of Cell Biology and Anatomy, Medical University \\ of South Carolina, Charleston, SC, USA \\ G. Ouyang \\ State Key Laboratory of Cellular Stress Biology, School of Life \\ Sciences, Xiamen University, Xiamen, China
}

J. R. Arron · C. T. J. Holweg

Genentech, 1 DNA Way, South San Francisco, CA, USA

A. Kudo ( $\square)$

Department of Biological Information, Tokyo Institute

of Technology, 4259 B-33, Nagatsuta, Midori-ku, Yokohama

226-8501, Japan

e-mail: akudo@bio.titech.ac.jp 
mouse osteoblast cell line [1, 2]. It is encoded by the Postn gene (genebank D13664) in humans, and to date, transforming growth factor beta (TGF- $\beta$ ) 1,2 , and 3 , bone morphogenetic proteins (BMP) 2 and 4, vascular endothelial growth factor, connective tissue growth factor 2, vitamin $\mathrm{K}$, valsartan (an angiotensin II antagonist), and interleukin (IL) 3, 4, 6, and 13 have all been reported to induce periostin expression in a cell-specific context [3].

Periostin is assigned to the family of fasciclins based on its homology to fasciclin I (FAS1), initially identified in insects. Proteins that share homology with FAS1 include $\beta$ ig-h3, stablin I and II, MBP-70, Algal-CAM, periostin, and periostin-like-factor 1 and 2 [1, 2, 4-8]. The four internal repeat regions of periostin share homology with an axon guidance protein FAS1, containing sequences that allow binding of integrins and glycosaminoglycans in vivo [9]. At the N-terminus, periostin has an EMI domain, which is a small cysteine-rich module of $\sim 75$ amino acids. The EMI domain was first named after its presence in proteins of the EMILIN family and is associated with other domains, such as C1q, laminin-type EGF-like, FN3, WAP, ZP, or FAS1 $[10,11]$.

In keeping with periostin's matricellular role as having regulatory rather than structural functions, periostin can interact with $\alpha \mathrm{v}$-integrins, induce activation of NF- $\mathrm{B} /$ STAT3 [12-14], PI3K/Akt [15], and FAK signaling [16], and modulate expression of multiple downstream genes including: $\alpha$-smooth muscle actin ( $\alpha \mathrm{SMA})$, collagen, fibronectin, aggrecan, sclerostin, chemokines, and TGF- $\beta 1$ [17-20].

Although periostin has been the target of a multitude of scientific publications since its first identification in 1993 $[1,2]$, almost all of the research has been conducted in narrowly defined areas. While considerable in-depth molecular knowledge on periostin is evolving in selected fields [21], the overall understanding of this intriguing molecule remains fragmented. As a matricellular protein, periostin has defined functions in osteology, tissue repair, oncology, cardiovascular and respiratory systems, and in various inflammatory settings and diseases. Extensive research has helped to elucidate its mechanism of action or role in many of these, yet there remain several disease states for which its mechanism of action is still unresolved. Emerging data associates periostin with Th2-associated inflammatory diseases, sparking research in several atopic conditions including bronchial asthma. Furthermore, although several different splice variants of periostin have been described $[3,22,23]$, their functional implications are as yet not fully understood. Potentially, distinct splice forms may be associated with different functions in various tissues and disease states.

The aim of this review is to (1) integrate the diverse evidence for the role of periostin across health and disease, and (2) identify an overarching mode of action for this pleiotropic matricellular molecule.

\section{Role of periostin in health and disease}

An overarching mode of action is not obviously apparent and has not been described to date in the wide range of tissues and diseases in which periostin has been reported. However, a closer analysis of the associated literature, detailed here, reveals a commonality related to structural remodeling as an upregulated responder to stress/challenge stimuli, regardless of physiology or disease. In this paper, we summarize the available evidence on periostin expression, its normal role in development, and whether it plays a similar function during pathologic repair, regeneration, and disease in order to bring together the disparate research fields in which periostin investigations are ongoing.

\section{Osteology}

Osteoblast-specific factor 2 was identified in 1993 in preosteoblasts and assigned a role in cell adhesion [2]. It was renamed periostin because of high levels of expression in the periosteum; the layer of connective tissue surrounding bone and responsible for intramembranous bone growth required for the increase in bone diameter, which is related to bone strength. Periostin is also highly expressed in the periodontal ligament (PDL) surrounding teeth and responsible for attaching them to the underlying bone [8, 24-27]. The PDL is the conduit for transmission of load to the bony mandible or maxilla and consequently is an important structure required to maintain healthy dentition and bone. In periostin (Postn) -/- mice, collagen fibrillogenesis was disrupted in the periosteum and studies on osteoblasts isolated from calvaria of these mice suggest a role in extracellular matrix (ECM) organization as well $[28,29]$. It is well recognized that both the bone and the ligament surrounding teeth respond to mechanical stress by remodeling. However, in Postn $-/-$ mice, mechanical loading resulted in disorganized collagen matrix formation and an increase in sclerostin mRNA suggesting a sclerostinmediated decrease in bone mass in these animals. Moreover, bone architecture in response to mechanical stress was restored with anti-sclerostin blocking antibody injections in these animals [19]. Therefore, under normal circumstances, periostin expression results in reduced sclerostin, thereby preserving bone mass and promoting bone remodeling. In the absence of periostin, the increase in sclerostin results in aberrant bone remodeling and a decrease in bone mass. However, as tendons are key in transmitting the force of contraction from muscle to bone, it is possible that in periostin null mice, tendon collagen organization is disrupted, 
interfering with effective transfer of force contraction from muscle to bone. Bone remodeling is then negatively affected in the absence of adequate loading (force). As the PDL performs an analogous function in teeth as do tendons in bone, findings from the loss of periostin in the knockout mouse in both of these tissues suggest a crucial role for periostin in mechanotransduction and response to mechanical loading and stress.

During embryogenesis and in the neonate, periostin isoforms are expressed in a specific temporal and spatial pattern, suggesting different functions for these variants in bone development and maturation [24]. In adults, periostin is re-expressed during fracture repair or in response to mechanical stress when bone development and remodeling is required [30]. A complete picture of the differential expression of the periostin isoforms is needed to understand the role of the variants in bone development, maturation, and repair. In vitro findings suggest that periostin's action on bone formation is through an increase in osteoblast proliferation, differentiation, adhesion, and survival [31]. The absence of periostin in knockout mouse models results in growth retardation and dwarfisms, shorter long-bones, and aberrant epiphyseal plate organization [19, 25], suggesting a role for periostin in bone development/remodeling and bone strength. Periostin mediates its effects on bone remodeling specifically by regulating collagen crosslinking and fibrillogenesis by binding to BMP1 via the EMI domain [32], or under conditions of mechanical stress by binding to Notch 1 and impacting osteoblast differentiation and cell death [33, 34]. In pathology, the expression of periostin is observed in fibrous dysplasia, a benign bone disease [35].

\section{Cutaneous and connective tissue remodeling}

Tissue regeneration in response to insult is associated with increased periostin expression [12]. However, this phenomenon is only transient, starting a few days post-injury, with protein levels peaking after 7 days and mRNA levels increasing slightly beforehand. Repetitive strain injuries have been associated with excess collagen deposition around myofibers, cell necrosis, infiltration of inflammatory cells, and increased cytokine expression. In addition, tendon and neural injuries can occur, leading to subsequent chronic inflammatory responses, followed by residual fibrosis [28, 36]. A periostin-like-factor was located in satellite cells and/or myoblasts, which increased in expression with continued task performance, supporting the hypothesis of a role in muscle repair and/or regeneration [37]. Furthermore, periostin has been shown to be expressed at basal levels in healthy human skin but localizes to the extracellular compartment during tissue remodeling involved in wound repair [38]. Recent studies indicate the contribution of periostin toward dermal regeneration and wound healing, suggesting that periostin may promote defect closure by facilitating the activation, differentiation, and contraction of fibroblasts $[12,13,39]$.

\section{Oncology}

Periostin overexpression is observed in various types of cancer [40], including thymoma [41], non-small cell lung carcinoma [42], breast cancer [43], pancreatic ductal adenocarcinoma [44], and in ascites from ovarian cancer patients [45]. It is believed to play a role during invasion, angiogenesis, and metastasis, as demonstrated by in vitro and in vivo experiments [40].

Solid tumor cells express high levels of periostin, yet the function of this matricellular protein during non-solid tumorigenesis and progression remains unclear. Periostin has been reported to promote tumor angiogenesis, migration, and metastases [46], and its overexpression has been shown to enhance invasion and anchorage-independent growth and spread in oral squamous-cell carcinoma [47]. Bao et al. [48] demonstrated that a colon cancer cell line with low metastatic potential, transduced to overexpress periostin, displayed accelerated metastatic growth, and that periostin activated the Akt/PKB pathway via the $\alpha \mathrm{v} \beta 3$ integrin to promote cancer cell survival. Supporting these observations, retrospective analyses of clinical studies have also shown that periostin expression is associated with a trend to metastasize and correlates with angiogenesis in oral, breast, and colon cancers [46, 48-50]. Furthermore, targeting periostin with a modified DNA aptamer, PNDA-3, that is capable of binding to periostin with high affinity and inhibiting its function, markedly antagonized adhesion, migration, and invasion of breast cancer cells both in vitro and in an in vivo orthotopic mouse breast cancer model [51]. Recent findings also suggest that periostin may have a role in sprouting neovascular endothelial tips of disseminated tumor cells, promoting breast cancer cell outgrowth in a tumor-suppressive microenvironment [52].

Periostin is a driver of the epithelial-mesenchymal transition (EMT) and induces expression of MMP-9, MMP10, and MMP-13, resulting in the degradation of ECM, believed to be crucial for local tumor spread and/or metastasis [53-55]. Furthermore, it is involved in remodeling the tumor microenvironment, which in turn promotes tumor survival, growth, and invasiveness [47]. This has also been described in the pancreatic parenchyma, in which periostin creates a tumor-supportive niche by sustaining fibrogenic stellate cell activity $[17,56]$, and in esophageal cancer, in which periostin facilitates tumor invasion $[57,58]$. Stromal periostin has also been indicated to play a critical role in metastatic colonization [59-61], by regulating the interactions between cancer stem cells and their metastatic niche. Moreover, stromal periostin has recently been reported to enhance cell attachment of clear cell renal cell carcinoma and proliferation of fibroblasts [62]. Periostin may bridge 
the gap between the metastatic microenvironment and cancer stem cells to promote metastatic spread by augmenting the Wnt signaling pathway $[59,60]$. Interestingly, periostin is highly expressed in human bone marrow mesenchymal stem cells and their derived adipocytes, chondrocytes, and osteoblasts. Periostin-overexpressing human mammary epithelial cells acquire part of the multi-lineage differentiation potentials of mesenchymal stem cells and promote tumor growth and metastasis of human breast cancer cell line [63]. These data indicate that periostin is a critical matricellular component in remodeling tissue microenvironment in tumor growth and metastasis.

\section{Cardiovascular}

Periostin is central in cardiovascular differentiation during in utero development of the cardiac valves and fibrous heart skeleton, and is re-expressed following myocardial injury. In detail, it promotes cardiac mesenchymal stem cell differentiation into fibrogenic lineages, is inhibitory to non-fibrogenic differentiation, and supports early valvulogenesis [18]. During neonatal remodeling, peak expression of periostin will induce collagen production, compaction, and fibroblast proliferation, mediating increased ventricular wall stiffness and valve functional maturation. In Postn $-/-$ mice, postnatal valve leaflets are truncated, interspersed with ectopic cardiomyocytes and smooth muscle, show impaired ECM composition, and exhibit reduced TGF- $\beta$ signaling [64]. Additionally, periostin is robustly expressed during annulus fibrosus development and abnormalities of this differentiation process may underlie development of certain forms of re-entrant atrioventricular tachycardia [65]. However, periostin is downregulated in the postnatal cardiac fibroblast lineage and remains at a low level of expression, but can be rapidly upregulated within cardiac fibroblast/myofibroblasts in response to insult/injury. It is robustly increased following pressure overload-induced left ventricular hypertrophy, and in turn downregulated after left ventricular hypertrophy regression in both animal and human models [66]. Similarly, periostin was markedly upregulated in mouse models of hypertrophic cardiomyopathy associated with non-myocyte proliferation and fibrosis. Abrogating periostin or TGF$\beta$ reduced or extinguished both proliferation and fibrosis and improved heart function [67].

In adult pathologic remodeling following cardiac injury or hypertension, periostin serum levels increase and are linked to accelerated mobilization, tissue engraftment, and differentiation of bone marrow cells into cardiac fibroblasts [68]. Additionally, genetic manipulation of Postn within the mouse has demonstrated that periostin itself within the heart does not affect myocyte content and cell cycle activity, but may facilitate scarless healing [69]. As a consequence, Postn $-/-$ mice are more prone to ventricular rupture within the first 10 days after myocardial infarction [22], yet survivors showed less fibrosis and better ventricular performance. Furthermore, inducible periostin overexpression protected mice from rupture following myocardial infarction but induced spontaneous hypertrophy with aging [70]. Periostin deposition has also been demonstrated to be involved in repair after vascular injury [71], and there is evidence that periostin insufficiency may contribute to valvular heart disease [3, 72], heart failure [66, 73], and atherosclerosis [74]. Elevated periostin in both normal and pathologic hearts is confined to the cardiac fibroblast (noncardiomyocyte) lineages, with TGF- $\beta 2$ being required for periostin expression [75]. Thus, Postn is currently being discussed as a potential target for prevention of heart failure $[66,73]$.

\section{Allergic and respiratory diseases}

Periostin has been reported to play a role in neonatal lung remodeling. Prolonged hyperoxic lung injury was shown to upregulate periostin, stimulating ectopic accumulation of myofibroblasts expressing $\alpha \mathrm{SMA}$, and leading to alveolar simplification [76]. Indeed, periostin expression is tightly correlated with the presence of $\alpha$ SMA-myofibroblasts, and its dysregulation may be a sensitive indicator of acutelyinhibited alveolar septation during a crucial window of lung remodeling [77].

It is evident that epithelial damage is commonplace in respiratory disease, be it from allergens or viral or bacterial infection. In the lung, periostin expression decreases following acute injury, but then increases substantially following TGF- $\beta$ activation and the initiation of repair mechanisms, but this may persist beyond the initial insult. Evidence suggests a close relationship between periostin and fibrogenesis in response to pulmonary injury [78].

There is a growing body of evidence regarding the role of periostin in asthma and type 2 inflammatory responses in particular [79-81]. Asthma symptoms in some patients may be exacerbated by chronic inflammation of the airways, largely mediated by type 2 inflammatory cytokines, in particular IL-13, which is produced by a variety of adaptive and innate immune cell types including CD4+ T cells, mast cells, basophils, and the recently described innate Th2 cells (ILC2) [82-85]. IL-13 and IL-4 can stimulate the production of periostin via activation of signal transducer and activator of transcription-6 (STAT6) [79, 80, 86]. Periostin expression is elevated in the bronchial epithelial cells of a subset of patients with asthma and is secreted basolaterally $[79,86]$. Periostin localizes to the basement membrane zone and the mesenchymal tissue compartment in the lung and colocalizes with other ECM proteins such as collagen, fibronectin, and tenascin- $C$ [78]. Periostin secreted by airway epithelial cells is able to activate TGF- $\beta$-mediated 
increases in type I collagen production in fibroblasts [86]. Periostin can facilitate the infiltration of eosinophils into sites of type 2 inflammation [87] and modulate IL-13 and IL-5-stimulated eosinophil adhesion and motility, suggesting that periostin may function as a haptotactic stimulus able to guide eosinophils to areas of high periostin density in the asthmatic airway [88], which may contribute to sustained eosinophil-mediated inflammation and fibrosis.

Persistent upregulation of periostin in the airway epithelium is likely to contribute to mechanisms of increased airway fibrosis and decreased airway distensibility [86]. Indeed, expression of periostin in airway epithelial cell brushings strongly correlates with subepithelial fibrosis in asthma [86]. The role of the type 2 inflammatory response and IL-13 in subepithelial fibrosis of bronchial asthma is also well established [89-92], and this has been reported to involve periostin as a downstream component, possibly by its binding to other ECM proteins [78]. The functional implications of elevated periostin have recently been investigated. In a Phase II clinical study of subjects with uncontrolled asthma, despite inhaled corticosteroids (ICS), it was demonstrated that periostin status predicted the response to an anti-IL-13 monoclonal antibody, lebrikizumab. Corren et al. [81] reported that lebrikizumab significantly improved lung function at 12 weeks, and that patients with high pretreatment levels of serum periostin had greater improvement in lung function than did patients with low periostin levels. In a different study (not involving lebrikizumab), following assessment of 224 asthmatic patients treated with ICS for at least 4 years, Kanemitsu et al. [93] reported that high serum periostin was one factor associated with an accelerated decline in $\mathrm{FEV}_{1}$. Polymorphisms of the POSTN gene were associated with both raised serum periostin levels and a decline in $\mathrm{FEV}_{1} \geq 30 \mathrm{~mL} / \mathrm{year}$, indicating that these may be useful to identify patients at risk of functional decline.
Furthermore, periostin has been linked with development of fibrosis in the pathogenesis of idiopathic interstitial pneumonia, and idiopathic pulmonary fibrosis (IPF) [94]. It is highly expressed in the lungs and serum of IPF patients in whom systemic periostin levels are inversely correlated with pulmonary function [95]. It has been suggested that periostin acts as an inducer of chemokines in the inflammatory response pivotal for the process of pulmonary fibrosis [20].

In addition, periostin has been implicated in atopic conditions such as dermatitis $[14,96]$ and rhinitis/rhinosinusitis [97]. In allergic skin inflammation, periostin induction after an initial injury contributes to the establishment of sustained chronic inflammation and tissue remodeling [14]. In chronic rhinosinusitis inflammation is mediated by the matricellular proteins periostin and osteopontin, leading to a proliferative response within the ECM framework and largely remodeling of the sinus histopathology [97].

\section{Miscellaneous inflammatory diseases}

Increased tissue periostin has been associated with several inflammatory conditions, in the fields of eosinophilia (e.g., otitis media [98], eosinophilic esophagitis [87]), ophthalmology (e.g., proliferative diabetic retinopathy [99]), hematology (e.g., bone marrow fibrosis [100]), and fibrotic remodeling (e.g., immunoglobulin G4-related sclerosing sialadenitis [101] and scleroderma [102]).

\section{Conclusions}

In spite of the multiple roles of periostin in health and disease (Table 1), tissue remodeling as a response to insult/ injury is emerging as a common functional denominator of

Table 1 Role of periostin in health and disease

\begin{tabular}{|c|c|c|c|}
\hline Tissue/disease & Health & Disease/repair & References \\
\hline Osteology & $\begin{array}{l}\text { Intramembranous bone growth, } \\
\text { bone development, collagen matrix } \\
\text { formation and mechanotransduction }\end{array}$ & Fracture repair or response to mechanical stress & {$[19,29,30]$} \\
\hline $\begin{array}{l}\text { Cutaneous and connective } \\
\text { tissue remodeling }\end{array}$ & Unknown & Muscle repair/regeneration, wound healing & {$[13,37,38]$} \\
\hline Oncology & NA & $\begin{array}{l}\text { Promote tumor angiogenesis, migration and } \\
\text { metastases, remodeling tumor microenvironment }\end{array}$ & {$[46,47,53-55]$} \\
\hline Cardiovascular & In utero development & $\begin{array}{l}\text { Response to pressure overload-induced left ventricular } \\
\text { hypertrophy, repair/remodeling following } \\
\text { myocardial infarction, repair after vascular injury }\end{array}$ & {$[18,22,68,71]$} \\
\hline $\begin{array}{l}\text { Allergic and respiratory } \\
\text { diseases }\end{array}$ & Neonatal lung remodeling & $\begin{array}{l}\text { Increased airway fibrosis, Th2-driven asthma, } \\
\text { and ECM protein binding }\end{array}$ & {$[76,78-81,87]$} \\
\hline Other inflammatory diseases & NA & Proliferation within the ECM framework & [97] \\
\hline
\end{tabular}

NA Not applicable 


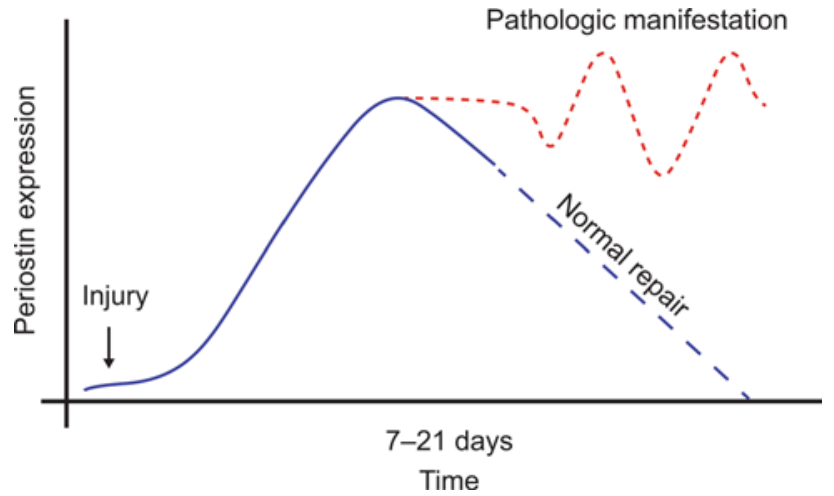

Fig. 1 Proposed schematic for transition of periostin's role in repair to pathologic conditions

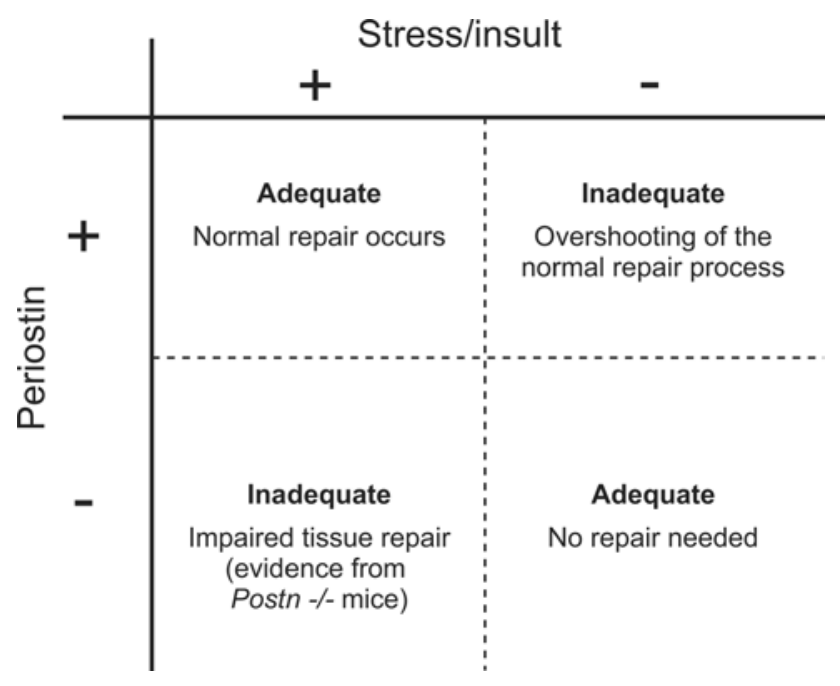

Fig. 2 Algorithm for role of periostin in response to stress

this matricellular molecule. Periostin is transiently upregulated during cell fate changes, either physiologic or pathologic. Combining observations across a vast expanse of molecular, biological and clinical areas of research, a common pattern of events may be suggested, including periostin localization into the area of development/insult, EMT, ECM restructuring, and eventually remodeling. Assessing the role of periostin by event rather than by disease suggests that any insult/injury such as inflammation, fibrosis, or EMT may be associated with a marked elevation of periostin levels, regardless of the target tissue or type of stimulus.

There is evidence that a periostin-rich microenvironment develops in areas associated with insult, such as injury and/or inflammation, orchestrating pathways of repair and rebuilding [38, 78]. Exposure to allergens in atopic diseases can be thought of as an insult, similar to what occurs in other inflammatory conditions, in which periostin expression is associated with remodeling, particularly fibrosis and ECM degradation. However, in the presence of inappropriately high and/or persisting periostin upregulation in the absence of an insult, an overshoot of the normal transient repair process can develop (Fig. 1).

Here, an algorithm may be hypothesized, where the appropriate response toward stress/insult is met by a transient periostin upregulation in the targeted tissue/organ (Fig. 2). If periostin expression is exhausted and/or not adequate, the tissue/organ may fail to remodel appropriately, leading to an insufficient response (e.g., mice with cardiac hypertrophy [70]). In contrast, a sustained upregulation of periostin, such as due to a recurring stimulus, could drive remodeling beyond the physiologic adaption and perpetuate, by itself, the disease state (e.g., mice with chronic skin inflammation [14].

Taken together, we propose mesenchymal remodeling as an overarching role for the matricellular protein periostin, across physiology and disease. Periostin may be seen as an important structural mediator in this remodeling process, balancing appropriate versus inappropriate tissue adaption in response to insult/injury.

Acknowledgments Support for third-party writing assistance for this manuscript, furnished by Jonathan Brennan of MediTech Media, UK, was provided by F. Hoffmann-La Roche Ltd.

Conflict of interest Kenji Izuhara has received a patent license fee from F. Hoffmann-La Roche Ltd, a personal consultant fee and grant from Chugai Pharmaceutical Co. Ltd, and a grant from Shinotest Co. Ltd. Judith Litvin, Roger Markwald, Simon J. Conway, Gaoliang Ouyang, Yasusei Kudo, Akira Kudo, have no conflict of interest. Joseph R. Arron and Cecile T.J. Holweg are employees of Genentech, a member of the Roche group and have an equity interest in Roche.

Open Access This article is distributed under the terms of the Creative Commons Attribution License which permits any use, distribution, and reproduction in any medium, provided the original author(s) and the source are credited.

\section{References}

1. Horiuchi K, Amizuka N, Takeshita S, Takamatsu H, Katsuura M, Ozawa H, Toyama Y, Bonewald LF, Kudo A (1999) Identification and characterization of a novel protein, periostin, with restricted expression to periosteum and periodontal ligament and increased expression by transforming growth factor beta. J Bone Miner Res 14:1239-1249

2. Takeshita S, Kikuno R, Tezuka K, Amann E (1993) Osteoblastspecific factor 2: cloning of a putative bone adhesion protein with homology with the insect protein fasciclin I. Biochem J 294:271-278

3. Norris RA, Moreno-Rodriguez R, Hoffman S, Markwald RR (2009) The many facets of the matricelluar protein periostin during cardiac development, remodeling, and pathophysiology. J Cell Commun Signal 3:275-286

4. Zinn K, McAllister L, Goodman CS (1988) Sequence analysis and neuronal expression of fasciclin I in grasshopper and Drosophila. Cell 53:577-587 
5. Terasaka K, Yamaguchi R, Matsuo K, Yamazaki A, Nagai S, Yamada T (1989) Complete nucleotide sequence of immunogenic protein MPB70 from Mycobacterium bovis BCG. FEMS Microbiol Lett 49:273-276

6. Skonier J, Neubauer M, Madisen L, Bennett K, Plowman GD, Purchio AF (1992) cDNA cloning and sequence analysis of beta ig-h3, a novel gene induced in a human adenocarcinoma cell line after treatment with transforming growth factor-beta. DNA Cell Biol 11:511-522

7. Huber O, Sumper M (1994) Algal-CAMs: isoforms of a cell adhesion molecule in embryos of the alga Volvox with homology to Drosophila fasciclin I. EMBO J 13:4212-4222

8. Litvin J, Selim AH, Montgomery MO, Lehmann K, Rico MC, Devlin H, Bednarik DP, Safadi FF (2004) Expression and function of periostin-isoforms in bone. J Cell Biochem 92:1044-1061

9. Elkins T, Hortsch M, Bieber AJ, Snow PM, Goodman CS (1990) Drosophila fasciclin I is a novel homophilic adhesion molecule that along with fasciclin III can mediate cell sorting. J Cell Biol 110:1825-1832

10. Doliana R, Bot S, Bonaldo P, Colombatti A (2000) EMI, a novel cysteine-rich domain of EMILINs and other extracellular proteins, interacts with the $\mathrm{gClq}$ domains and participates in multimerization. FEBS Lett 484:164-168

11. Callebaut I, Mignotte V, Souchet M, Mornon JP (2003) EMI domains are widespread and reveal the probable orthologs of the Caenorhabditis elegans CED-1 protein. Biochem Biophys Res Commun 300:619-623

12. Ontsuka K, Kotobuki Y, Shiraishi H, Serada S, Ohta S, Tanemura A, Yang L, Fujimoto M, Arima K, Suzuki S, Murota H, Toda S, Kudo A, Conway SJ, Narisawa Y, Katayama I, Izuhara K, Naka T (2012) Periostin, a matricellular protein, accelerates cutaneous wound repair by activating dermal fibroblasts. Exp Dermatol 21:331-336

13. Nishiyama T, Kii I, Kashima TG, Kikuchi Y, Ohazama A, Shimazaki M, Fukayama M, Kudo A (2011) Delayed re-epithelialization in periostin-deficient mice during cutaneous wound healing. PLoS ONE 6:e18410

14. Masuoka M, Shiraishi H, Ohta S, Suzuki S, Arima K, Aoki S, Toda S, Inagaki N, Kurihara Y, Hayashida S, Takeuchi S, Koike K, Ono J, Noshiro H, Furue M, Conway SJ, Narisawa Y, Izuhara K (2012) Periostin promotes chronic allergic inflammation in response to Th2 cytokines. J Clin Invest 122:2590-2600

15. Yang L, Serada S, Fujimoto M, Terao M, Kotobuki Y, Kitaba S, Matsui S, Kudo A, Naka T, Murota H, Katayama I (2012) Periostin facilitates skin sclerosis via PI3K/Akt dependent mechanism in a mouse model of scleroderma. PLoS ONE 7:e41994

16. Li G, Jin R, Norris RA, Zhang L, Yu S, Wu F, Markwald RR, Nanda A, Conway SJ, Smyth SS, Granger DN (2010) Periostin mediates vascular smooth muscle cell migration through the integrins alphavbeta 3 and alphavbeta5 and focal adhesion kinase (FAK) pathway. Atherosclerosis 208:358-365

17. Erkan M, Kleeff J, Gorbachevski A, Reiser C, Mitkus T, Esposito I, Giese T, Buchler MW, Giese NA, Friess H (2007) Periostin creates a tumor-supportive microenvironment in the pancreas by sustaining fibrogenic stellate cell activity. Gastroenterology 132:1447-1464

18. Snider P, Hinton RB, Moreno-Rodriguez RA, Wang J, Rogers R, Lindsley A, Li F, Ingram DA, Menick D, Field L, Firulli AB, Molkentin JD, Markwald R, Conway SJ (2008) Periostin is required for maturation and extracellular matrix stabilization of noncardiomyocyte lineages of the heart. Circ Res 102:752-760

19. Bonnet N, Standley KN, Bianchi EN, Stadelmann V, Foti M, Conway SJ, Ferrari SL (2009) The matricellular protein periostin is required for sost inhibition and the anabolic response to mechanical loading and physical activity. J Biol Chem 284:35939-35950

20. Uchida M, Shiraishi H, Ohta S, Arima K, Taniguchi K, Suzuki S, Okamoto M, Ahlfeld SK, Ohshima K, Kato S, Toda S, Sagara H, Aizawa H, Hoshino T, Conway SJ, Hayashi S, Izuhara K (2012) Periostin, a matricellular protein, plays a role in the induction of chemokines in pulmonary fibrosis. Am J Respir Cell Mol Biol 46:677-686

21. Kudo A (2011) Periostin in fibrillogenesis for tissue regeneration: periostin actions inside and outside the cell. Cell Mol Life Sci 68:3201-3207

22. Shimazaki M, Nakamura K, Kii I, Kashima T, Amizuka N, Li M, Saito M, Fukuda K, Nishiyama T, Kitajima S, Saga Y, Fukayama M, Sata M, Kudo A (2008) Periostin is essential for cardiac healing after acute myocardial infarction. J Exp Med 205:295-303

23. Takayama I, Kudo A (2012) Periostin in dental science. Jpn Dent Sci Rev 48:92-98

24. Zhu S, Barbe MF, Amin N, Rani S, Popoff SN, Safadi FF, Litvin J (2008) Immunolocalization of periostin-like factor and periostin during embryogenesis. J Histochem Cytochem 56:329-345

25. Rios H, Koushik SV, Wang H, Wang J, Zhou HM, Lindsley A, Rogers R, Chen Z, Maeda M, Kruzynska-Frejtag A, Feng JQ, Conway SJ (2005) Periostin null mice exhibit dwarfism, incisor enamel defects, and an early-onset periodontal disease-like phenotype. Mol Cell Biol 25:11131-11144

26. Ma D, Zhang R, Sun Y, Rios HF, Haruyama N, Han X, Kulkarni AB, Qin C, Feng JQ (2011) A novel role of periostin in postnatal tooth formation and mineralization. J Biol Chem 286:4302-4309

27. Kii I, Amizuka N, Minqi L, Kitajima S, Saga Y, Kudo A (2006) Periostin is an extracellular matrix protein required for eruption of incisors in mice. Biochem Biophys Res Commun 342:766-772

28. Norris RA, Damon B, Mironov V, Kasyanov V, Ramamurthi A, Moreno-Rodriguez R, Trusk T, Potts JD, Goodwin RL, Davis J, Hoffman S, Wen X, Sugi Y, Kern CB, Mjaatvedt CH, Turner DK, Oka T, Conway SJ, Molkentin JD, Forgacs G, Markwald RR (2007) Periostin regulates collagen fibrillogenesis and the biomechanical properties of connective tissues. J Cell Biochem 101:695-711

29. Kii I, Nishiyama T, Li M, Matsumoto K, Saito M, Amizuka N, Kudo A (2010) Incorporation of tenascin-C into the extracellular matrix by periostin underlies an extracellular meshwork architecture. J Biol Chem 285:2028-2039

30. Nakazawa T, Nakajima A, Seki N, Okawa A, Kato M, Moriya H, Amizuka N, Einhorn TA, Yamazaki M (2004) Gene expression of periostin in the early stage of fracture healing detected by cDNA microarray analysis. J Orthop Res 22:520-525

31. Zhu S, Barbe MF, Liu C, Hadjiargyrou M, Popoff SN, Rani S, Safadi FF, Litvin J (2009) Periostin-like-factor in osteogenesis. J Cell Physiol 218:584-592

32. Maruhashi T, Kii I, Saito M, Kudo A (2010) Interaction between periostin and BMP-1 promotes proteolytic activation of lysyl oxidase. J Biol Chem 285:13294-13303

33. Merle B, Garnero P (2012) The multiple facets of periostin in bone metabolism. Osteoporos Int 23:1199-1212

34. Tanabe H, Takayama I, Nishiyama T, Shimazaki M, Kii I, Li M, Amizuka N, Katsube K, Kudo A (2010) Periostin associates with Notch1 precursor to maintain Notch1 expression under a stress condition in mouse cells. PLoS ONE 5:e12234

35. Kashima TG, Nishiyama T, Shimazu K, Shimazaki M, Kii I, Grigoriadis AE, Fukayama M, Kudo A (2009) Periostin, a novel marker of intramembranous ossification, is expressed in fibrous 
dysplasia and in c-Fos-overexpressing bone lesions. Hum Pathol 40:226-237

36. Rani S, Barbe MF, Barr AE, Litvin J (2009) Induction of periostin-like factor and periostin in forearm muscle, tendon, and nerve in an animal model of work-related musculoskeletal disorder. J Histochem Cytochem 57:1061-1073

37. Rani S, Barbe MF, Barr AE, Litvin J (2009) Periostin-like-factor and Periostin in an animal model of work-related musculoskeletal disorder. Bone 44:502-512

38. Jackson-Boeters L, Wen W, Hamilton DW (2009) Periostin localizes to cells in normal skin, but is associated with the extracellular matrix during wound repair. J Cell Commun Signal 3:125-133

39. Elliott CG, Wang J, Guo X, Xu SW, Eastwood M, Guan J, Leask A, Conway SJ, Hamilton DW (2012) Periostin modulates myofibroblast differentiation during full-thickness cutaneous wound repair. J Cell Sci 125:121-132

40. Ruan K, Bao S, Ouyang G (2009) The multifaceted role of periostin in tumorigenesis. Cell Mol Life Sci 66:2219-2230

41. Sasaki H, Dai M, Auclair D, Kaji M, Fukai I, Kiriyama M, Yamakawa Y, Fujii Y, Chen LB (2001) Serum level of the periostin, a homologue of an insect cell adhesion molecule, in thymoma patients. Cancer Lett 172:37-42

42. Sasaki H, Dai M, Auclair D, Fukai I, Kiriyama M, Yamakawa Y, Fujii Y, Chen LB (2001) Serum level of the periostin, a homologue of an insect cell adhesion molecule, as a prognostic marker in nonsmall cell lung carcinomas. Cancer 92:843-848

43. Sasaki H, Yu CY, Dai M, Tam C, Loda M, Auclair D, Chen LB, Elias A (2003) Elevated serum periostin levels in patients with bone metastases from breast but not lung cancer. Breast Cancer Res Treat 77:245-252

44. Baril P, Gangeswaran R, Mahon PC, Caulee K, Kocher HM, Harada T, Zhu M, Kalthoff H, Crnogorac-Jurcevic T, Lemoine NR (2007) Periostin promotes invasiveness and resistance of pancreatic cancer cells to hypoxia-induced cell death: role of the beta 4 integrin and the PI $3 \mathrm{k}$ pathway. Oncogene 26:2082-2094

45. Gillan L, Matei D, Fishman DA, Gerbin CS, Karlan BY, Chang DD (2002) Periostin secreted by epithelial ovarian carcinoma is a ligand for alpha(V)beta(3) and alpha(V)beta(5) integrins and promotes cell motility. Cancer Res 62:5358-5364

46. Siriwardena BS, Kudo Y, Ogawa I, Kitagawa M, Kitajima S, Hatano H, Tilakaratne WM, Miyauchi M, Takata T (2006) Periostin is frequently overexpressed and enhances invasion and angiogenesis in oral cancer. Br J Cancer 95:1396-1403

47. Kudo Y, Ogawa I, Kitajima S, Kitagawa M, Kawai H, Gaffney PM, Miyauchi M, Takata T (2006) Periostin promotes invasion and anchorage-independent growth in the metastatic process of head and neck cancer. Cancer Res 66:6928-6935

48. Bao S, Ouyang G, Bai X, Huang Z, Ma C, Liu M, Shao R, Anderson RM, Rich JN, Wang XF (2004) Periostin potently promotes metastatic growth of colon cancer by augmenting cell survival via the Akt/PKB pathway. Cancer Cell 5:329-339

49. Shao R, Bao S, Bai X, Blanchette C, Anderson RM, Dang T, Gishizky ML, Marks JR, Wang XF (2004) Acquired expression of periostin by human breast cancers promotes tumor angiogenesis through up-regulation of vascular endothelial growth factor receptor 2 expression. Mol Cell Biol 24:3992-4003

50. Kikuchi Y, Kashima TG, Nishiyama T, Shimazu K, Morishita Y, Shimazaki M, Kii I, Horie H, Nagai H, Kudo A, Fukayama M (2008) Periostin is expressed in pericryptal fibroblasts and cancer-associated fibroblasts in the colon. J Histochem Cytochem 56:753-764

51. Lee YJ, Kim IS, Park SA, Kim Y, Lee JE, Noh DY, Kim KT, Ryu SH, Suh PG (2013) Periostin-binding DNA aptamer inhibits breast cancer growth and metastasis. Mol Ther 21:1004-1013

52. Ghajar CM, Peinado H, Mori H, Matei IR, Evason KJ, Brazier H, Almeida D, Koller A, Hajjar KA, Stainier DY, Chen EI, Lyden D, Bissell MJ (2013) The perivascular niche regulates breast tumour dormancy. Nat Cell Biol 15:807-817

53. Deraz EM, Kudo Y, Yoshida M, Obayashi M, Tsunematsu T, Tani H, Siriwardena SB, Keikhaee MR, Qi G, lizuka S, Ogawa I, Campisi G, Lo ML, Abiko Y, Kikuchi A, Takata T (2011) MMP-10/stromelysin-2 promotes invasion of head and neck cancer. PLoS ONE 6:e25438

54. Kudo Y, lizuka S, Yoshida M, Tsunematsu T, Kondo T, Subarnbhesaj A, Deraz EM, Siriwardena SB, Tahara H, Ishimaru N, Ogawa I, Takata T (2012) Matrix metalloproteinase-13 (MMP13) directly and indirectly promotes tumor angiogenesis. J Biol Chem 287:38716-38728

55. Kudo Y, Iizuka S, Yoshida M, Nguyen PT, Siriwardena SB, Tsunematsu T, Ohbayashi M, Ando T, Hatakeyama D, Shibata T, Koizumi K, Maeda M, Ishimaru N, Ogawa I, Takata T (2012) Periostin directly and indirectly promotes tumor lymphangiogenesis of head and neck cancer. PLoS ONE 7:e44488

56. Fukushima N, Kikuchi Y, Nishiyama T, Kudo A, Fukayama M (2008) Periostin deposition in the stroma of invasive and intraductal neoplasms of the pancreas. Mod Pathol 21:1044-1053

57. Michaylira CZ, Wong GS, Miller CG, Gutierrez CM, Nakagawa H, Hammond R, Klein-Szanto AJ, Lee JS, Kim SB, Herlyn M, Diehl JA, Gimotty P, Rustgi AK (2010) Periostin, a cell adhesion molecule, facilitates invasion in the tumor microenvironment and annotates a novel tumor-invasive signature in esophageal cancer. Cancer Res 70:5281-5292

58. Wong GS, Lee JS, Park YY, Klein-Szanto AJ, Waldron TJ, Cukierman E, Herlyn M, Gimotty P, Nakagawa H, Rustgi AK (2013) Periostin cooperates with mutant p53 to mediate invasion through the induction of STAT1 signaling in the esophageal tumor microenvironment. Oncogenesis 2:e59

59. Malanchi I, Santamaria-Martinez A, Susanto E, Peng H, Lehr HA, Delaloye JF, Huelsken J (2012) Interactions between cancer stem cells and their niche govern metastatic colonization. Nature 481:85-89

60. Wang Z, Ouyang G (2012) Periostin: a bridge between cancer stem cells and their metastatic niche. Cell Stem Cell 10:111-112

61. Shimazaki M, Kudo A (2008) Impaired capsule formation of tumors in periostin-null mice. Biochem Biophys Res Commun 367:736-742

62. Bakhtyar N, Wong N, Kapoor A, Cutz JC, Hill B, Ghert M, Tang D (2013) Clear cell renal cell carcinoma induces fibroblast-mediated production of stromal periostin. Eur J Cancer 49:3537-3546

63. Wang X, Liu J, Wang Z, Huang Y, Liu W, Zhu X, Cai Y, Fang X, Lin S, Yuan L, Ouyang G (2013) Periostin contributes to the acquisition of multipotent stem cell-like properties in human mammary epithelial cells and breast cancer cells. PLoS ONE 8:e72962

64. Conway SJ, Molkentin JD (2008) Periostin as a heterofunctional regulator of cardiac development and disease. Curr Genomics 9:548-555

65. Zhou B, von Gise A, Ma Q, Hu YW, Pu WT (2010) Genetic fate mapping demonstrates contribution of epicardium-derived cells to the annulus fibrosis of the mammalian heart. Dev Biol 338:251-261

66. Stansfield WE, Andersen NM, Tang RH, Selzman CH (2009) Periostin is a novel factor in cardiac remodeling after experimental and clinical unloading of the failing heart. Ann Thorac Surg 88:1916-1921 
67. Teekakirikul P, Eminaga S, Toka O, Alcalai R, Wang L, Wakimoto H, Nayor M, Konno T, Gorham JM, Wolf CM, Kim JB, Schmitt JP, Molkentin JD, Norris RA, Tager AM, Hoffman SR, Markwald RR, Seidman CE, Seidman JG (2010) Cardiac fibrosis in mice with hypertrophic cardiomyopathy is mediated by non-myocyte proliferation and requires Tgf-beta. J Clin Invest 120:3520-3529

68. Kuhn B, del Monte F, Hajjar RJ, Chang YS, Lebeche D, Arab S, Keating MT (2007) Periostin induces proliferation of differentiated cardiomyocytes and promotes cardiac repair. Nat Med 13:962-969

69. Lorts A, Schwanekamp JA, Elrod JW, Sargent MA, Molkentin JD (2009) Genetic manipulation of periostin expression in the heart does not affect myocyte content, cell cycle activity, or cardiac repair. Circ Res 104:e1-e7

70. Oka T, Xu J, Kaiser RA, Melendez J, Hambleton M, Sargent MA, Lorts A, Brunskill EW, Dorn GW, Conway SJ, Aronow BJ, Robbins J, Molkentin JD (2007) Genetic manipulation of periostin expression reveals a role in cardiac hypertrophy and ventricular remodeling. Circ Res 101:313-321

71. Lindner V, Wang Q, Conley BA, Friesel RE, Vary CP (2005) Vascular injury induces expression of periostin: implications for vascular cell differentiation and migration. Arterioscler Thromb Vasc Biol 25:77-83

72. Hakuno D, Kimura N, Yoshioka M, Mukai M, Kimura T, Okada Y, Yozu R, Shukunami C, Hiraki Y, Kudo A, Ogawa S, Fukuda K (2010) Periostin advances atherosclerotic and rheumatic cardiac valve degeneration by inducing angiogenesis and MMP production in humans and rodents. J Clin Invest 120:2292-2306

73. Asakura M, Kitakaze M (2009) Global gene expression profiling in the failing myocardium. Circ J 73:1568-1576

74. Hixson JE, Shimmin LC, Montasser ME, Kim DK, Zhong Y, Ibarguen H, Follis J, Malcom G, Strong J, Howard T, Langefeld C, Liu Y, Rotter JI, Johnson C, Herrington D (2011) Common variants in the periostin gene influence development of atherosclerosis in young persons. Arterioscler Thromb Vasc Biol 31:1661-1667

75. Snider P, Standley KN, Wang J, Azhar M, Doetschman T, Conway SJ (2009) Origin of cardiac fibroblasts and the role of periostin. Circ Res 105:934-947

76. Bozyk PD, Bentley JK, Popova AP, Anyanwu AC, Linn MD, Goldsmith AM, Pryhuber GS, Moore BB, Hershenson MB (2012) Neonatal periostin knockout mice are protected from hyperoxia-induced alveolar simplication. PLoS ONE 7:e31336

77. Ahlfeld SK, Gao Y, Wang J, Horgusluoglu E, Bolanis E, Clapp DW, Conway SJ (2013) Periostin downregulation is an early marker of inhibited neonatal murine lung alveolar septation. Birth Defects Res A Clin Mol Teratol 97:373-385

78. Takayama G, Arima K, Kanaji T, Toda S, Tanaka H, Shoji S, McKenzie AN, Nagai H, Hotokebuchi T, Izuhara K (2006) Periostin: a novel component of subepithelial fibrosis of bronchial asthma downstream of IL-4 and IL-13 signals. J Allergy Clin Immunol 118:98-104

79. Woodruff PG, Boushey HA, Dolganov GM, Barker CS, Yang YH, Donnelly S, Ellwanger A, Sidhu SS, Dao-Pick TP, Pantoja C, Erle DJ, Yamamoto KR, Fahy JV (2007) Genome-wide profiling identifies epithelial cell genes associated with asthma and with treatment response to corticosteroids. Proc Natl Acad Sci USA 104:15858-15863

80. Woodruff PG, Modrek B, Choy DF, Jia G, Abbas AR, Ellwanger A, Koth LL, Arron JR, Fahy JV (2009) T-helper type 2-driven inflammation defines major subphenotypes of asthma. Am J Respir Crit Care Med 180:388-395

81. Corren J, Lemanske RF, Hanania NA, Korenblat PE, Parsey MV, Arron JR, Harris JM, Scheerens H, Wu LC, Su Z, Mosesova S, Eisner MD, Bohen SP, Matthews JG (2011)
Lebrikizumab treatment in adults with asthma. N Engl J Med 365:1088-1098

82. Humbert M, Durham SR, Kimmitt P, Powell N, Assoufi B, Pfister R, Menz G, Kay AB, Corrigan CJ (1997) Elevated expression of messenger ribonucleic acid encoding IL-13 in the bronchial mucosa of atopic and nonatopic subjects with asthma. J Allergy Clin Immunol 99:657-665

83. Grunig G, Warnock M, Wakil AE, Venkayya R, Brombacher F, Rennick DM, Sheppard D, Mohrs M, Donaldson DD, Locksley RM, Corry DB (1998) Requirement for IL-13 independently of IL-4 in experimental asthma. Science 282:2261-2263

84. Wills-Karp M, Luyimbazi J, Xu X, Schofield B, Neben TY, Karp CL, Donaldson DD (1998) Interleukin-13: central mediator of allergic asthma. Science 282:2258-2261

85. Hershey GK (2003) IL-13 receptors and signaling pathways: an evolving web. J Allergy Clin Immunol 111:677-690

86. Sidhu SS, Yuan S, Innes AL, Kerr S, Woodruff PG, Hou L, Muller SJ, Fahy JV (2010) Roles of epithelial cell-derived periostin in TGF-beta activation, collagen production, and collagen gel elasticity in asthma. Proc Natl Acad Sci USA 107:14170-14175

87. Blanchard C, Mingler MK, McBride M, Putnam PE, Collins MH, Chang G, Stringer K, Abonia JP, Molkentin JD, Rothenberg ME (2008) Periostin facilitates eosinophil tissue infiltration in allergic lung and esophageal responses. Mucosal Immunol 1:289-296

88. Johansson M, Annis D, Mosher D (2013) AlphaMbeta2 integrin-mediated adhesion and motility of interleukin-5-stimulated eosinophils on periostin. (abstract). Am J Respir Crit Care Med 187:A2064

89. Zhu Z, Homer RJ, Wang Z, Chen Q, Geba GP, Wang J, Zhang Y, Elias JA (1999) Pulmonary expression of interleukin-13 causes inflammation, mucus hypersecretion, subepithelial fibrosis, physiologic abnormalities, and eotaxin production. J Clin Invest 103:779-788

90. Foster PS, Ming Y, Matthei KI, Young IG, Temelkovski J, Kumar RK (2000) Dissociation of inflammatory and epithelial responses in a murine model of chronic asthma. Lab Invest 80:655-662

91. Kumar RK, Herbert C, Yang M, Koskinen AM, McKenzie AN, Foster PS (2002) Role of interleukin-13 in eosinophil accumulation and airway remodelling in a mouse model of chronic asthma. Clin Exp Allergy 32:1104-1111

92. Komai M, Tanaka H, Masuda T, Nagao K, Ishizaki M, Sawada M, Nagai H (2003) Role of Th2 responses in the development of allergen-induced airway remodelling in a murine model of allergic asthma. Br J Pharmacol 138:912-920

93. Kanemitsu Y, Matsumoto H, Izuhara K, Tohda Y, Kita H, Horiguchi T, Kuwabara K, Tomii K, Otsuka K, Fujimura M, Ohkura N, Tomita K, Yokoyama A, Ohnishi H, Nakano Y, Oguma T, Hozawa S, Nagasaki T, Ito I, Oguma T, Inoue H, Tajiri T, Iwata T, Izuhara Y, Ono J, Ohta S, Tamari M, Hirota T, Yokoyama T, Niimi A, Mishima M (2013) Increased periostin associates with greater airflow limitation in patients receiving inhaled corticosteroids. J Allergy Clin Immunol 132:305-312

94. Naik PK, Bozyk PD, Bentley JK, Popova AP, Birch CM, Wilke CA, Fry CD, White ES, Sisson TH, Tayob N, Carnemolla B, Orecchia P, Flaherty KR, Hershenson MB, Murray S, Martinez FJ, Moore BB (2012) Periostin promotes fibrosis and predicts progression in patients with idiopathic pulmonary fibrosis. Am $\mathbf{J}$ Physiol Lung Cell Mol Physiol 303:L1046-L1056

95. Okamoto M, Hoshino T, Kitasato Y, Sakazaki Y, Kawayama T, Fujimoto K, Ohshima K, Shiraishi H, Uchida M, Ono J, Ohta S, Kato S, Izuhara K, Aizawa H (2011) Periostin, a matrix protein, is a novel biomarker for idiopathic interstitial pneumonias. Eur Respir J 37:1119-1127

96. Shiraishi H, Masuoka M, Ohta S, Suzuki S, Arima K, Taniguchi K, Aoki S, Toda S, Yoshimoto T, Inagaki N, Conway SJ, 
Narisawa Y, Izuhara K (2012) Periostin contributes to the pathogenesis of atopic dermatitis by inducing TSLP production from keratinocytes. Allergol Int 61:563-572

97. Ishida A, Ohta N, Suzuki Y, Kakehata S, Okubo K, Ikeda H, Shiraishi H, Izuhara K (2012) Expression of pendrin and periostin in allergic rhinitis and chronic rhinosinusitis. Allergol Int 61:589-595

98. Nishizawa H, Matsubara A, Nakagawa T, Ohta N, Izuhara K, Shirasaki T, Abe T, Takeda I, Shinkawa H (2012) The role of periostin in eosinophilic otitis media. Acta Otolaryngol 132:838-844

99. Yoshida S, Ishikawa K, Asato R, Arima M, Sassa Y, Yoshida A, Yoshikawa H, Narukawa K, Obika S, Ono J, Ohta S, Izuhara K, Kono T, Ishibashi T (2011) Increased expression of periostin in vitreous and fibrovascular membranes obtained from patients with proliferative diabetic retinopathy. Invest Ophthalmol Vis Sci 52:5670-5678

100. Oku E, Kanaji T, Takata Y, Oshima K, Seki R, Morishige S, Imamura R, Ohtsubo K, Hashiguchi M, Osaki K, Yakushiji K, Yoshimoto K, Ogata H, Hamada H, Izuhara K, Sata M, Okamura T (2008) Periostin and bone marrow fibrosis. Int J Hematol 88:57-63

101. Ohta N, Kurakami K, Ishida A, Furukawa T, Saito F, Kakehata S, Izuhara K (2012) Clinical and pathological characteristics of IgG4-related sclerosing sialadenitis. Laryngoscope 122:572-577

102. Yamaguchi Y, Ono J, Masuoka M, Ohta S, Izuhara K, Ikezawa Z, Aihara M, Takahashi K (2012) Serum periostin levels are correlated with progressive skin sclerosis in patients with systemic sclerosis. Br J Dermatol 168:717-725 